\title{
ПОСТМОДЕРНІСТСЬКІ ПІДХОДИ У ВИБОРЧІЙ КАМПАНІЇ ПРЕЗИДЕНТА УКРАЇНИ
}

\author{
Діана ГРУШАНСЬКА \\ Аспірант Кам’янець-Подільського національного університету імені І.Огієнка, \\ УКРӒ̈НА
}

\section{DOI 10.25128/2304-1222.19.48.10}

The article anal yzes the influence on the course of the election campaign of the current President of Ukraine Volodymyr Zelensky of the basic ideas and principles of postmodernism The main changes in the approach to the understanding of the term "politics", "politician", "policy language" are noted.

Keywords: postmodernism power, society, changes.

У статті аналізується вплив на перетік виборчої кампанії нинішнього Президента України Володимира Зеленського основних ідей та принципів постмодернізму. Відзначаються основні зміни у підході до розуміння терміну «політика», «політик», «мова політики».

Ключові слова: постмодернізм, влада, суспільство, зміни.

W artykule jest analizowany wpływ podstawowych idei i zasad postmodernizmu na przebieg kampanii wyborczej obecnego prezydenta Ukrainy Władimira Zeleńskiego. Odnotowano główne zmiany w podejściu do rozumienia terminów ,polityka”, ,ppolitycy” i ,język polityki”.

Słowa kluczowe: postmodernizm, władza, społeczeństwo, zmiany.

Сьогодні більшість країн переходять у нову еру - еру постмодерну. Цей напрям став реакцією на ідеологічну кризу гуманізму після Другої світової війни, також увібрав авангардистську «втому від культури», пересиченість культури («все вже написано»). Український науковець А. Постол зазначає що під цим поняттям сьогодні розуміють глобальний стан цивілізації останніх десятиліть, який характеризується великою кількістю невизначеностей в усіх сферах життєдіяльності [Постол 2010: 4].

Відповідно, нові цінності та ідеали переносяться також на політику. Вияв основних складових постмодерну і їхній вплив на результати виборів в Україні є метою статті, а висвітлення трансформацій влади, змін у системі цінностей, «перетворень» держави - становлять мету дослідження. При цьому об'єктом виступає постмодерністський вимір сучасної цивілізації, а предметом - суспільно-політичні зміни, їх конкретні прояви у глобалізованому соціумі. 
Дослідники постмодернізму, серед яких А.Тойнбі, А.Етціоні, Р.Інглхарт, Ж.Ф.Ліотар, Ч.Дженкс, З.Бауман, Д.Белл, М.Хайдегер, Ігаб Гассан, В.Вельш, П.Козловскі, О.Панарін, В.Воронкова, В.Горбатенко, Д.Затонський, Н.Терещенко, Т.Шатунова та ін. розглядають постмодернізм з різних позицій і стверджують, що його постулати торкаються усіх сфер людської діяльності. Найсуттєвішими ознаками постмодернізму є використання готових форм та іронія, а також сприйняття світу як текст.

Перемога Зеленського на Президентських виборах 2019 стала для України рекордною - оскільки такого великого розриву між кандидатами не спостерігалося іще ні разу за всі роки незалежності країни. За результатами ЦВК Володимир Зеленський отримав 73,22\% голосів, а Петро Порошенко - 24,45\%. Більшість експертів пояснювали це тим, що суттєво на ситуацію вплинув серіал «Слуга народу», де Зеленський грає роль Президента, і також неодноразово використовували твердження «актор став Президентом». Соціолог та директорка Фонду "Демократичні Ініціативи" Ірина Бекешкіна стверджувала: « Був великий вибір, а проголосували за людину, яка взагалі до політики не має ніякого відношення. Це вирок українській політиці і політичному класу в цілому».

Натомість, проаналізувавши основні концепції постмодерністів та їхні теорії про функціонування сучасного світу та свідомості людини, можна припустити, що ті способи, якими користувався у своїй виборчій кампанії В. Зеленський цілком логічно привели його до перемоги.

Український науковець В.Горбатенко пише, що його основними рисами постмодерну є «відкритість, фрагментарність, визволення, плюралізм, руйнування зцентрованої структури, еклектичність, іронія, пародія, саморефлексійність, кітч, гра» [Горбатенко 2006: 27]. 3 постмодерном також асоціюються невизначеність, відсутність канонів, карнавалізація, перфоманс, взаємодія.

Саме такі риси можна відмітити у політичних гаслах В. Зеленського - зокрема, «Весна прийде - будемо саджати», «Постав галочку - закрий їм лавочку», «Весна покаже хто де крав». Один із фундаторів вчення про нову епоху, Мартін Гайдеггер, особливо увагу у дослідженні приділяв мові. Він зазначає, що в епоху постмодернізму, «особистість помирає, індивідуальність розчиняється в посередництві мови» [Хайдеггер: 30]. Серед особливостей мови метафізики науковець 
стверджує, що «людина як автор, відповідальний суб’єкт мови, вільно маніпулює словами, надає їм значення і сенс на свій смак. Мова вважається засобом передачі думок, слухняною зброєю в руках у людини, спосіб передачі інформації - підкреслює Гайдеггер. «Мову варто розглядати не лише як потужну зброю правлячої еліти, а набагато ширше: це є спосіб вираження тих непомітних і прихованих тверджень, на яких будується уся західна культура. Він поставлений на службу певної ідеології», - стверджує філософ [Хайдеггер: 46]. Відповідно, саме мова є визначальною в налагодженні ефективної комунікації між електоратом і кандидатом.

Деякі експерти виокремлюють також серіал «Слуга народа» як окремий інструмент, що відіграв суттєву роль для перемоги кандидата Зеленського. Натомість це твердження є хибним, оскільки інструмент - це є засіб, спосіб для досягнення чого-небудь. А наразі не можна стверджувати, що творці телесеріалу мали на меті згодом саме просування В. Зеленського у Президенти. Політичний телесеріал «Слуга народа» вийшов 16 листопада 2015 року, партія «Слуга народа», за даними Мін'юсту, була зареєстрована 13 квітня 2016 року (спочатку мала назву «Партія рішучих змін», перейменована 2 грудня 2017 року).

Соцмережі - наступний критерій, який активно використовувався у виборчій кампанії В. Зеленського. Варто відзначити, що соціальні мережі не приймають традиційну консервативну риторику, тому більшість тез та висловів були детально опрацьовані перед публікацією. Відповідно, політика перенеслася на екрани. I в цьому випадку важливо постійно підживляти до неї інтерес завдяки суперечкам та провокаціям. Український науковець В. Горбатенко зазначає: «Політичній діяльності постмодерністського типу властиві фрагментарність, гра в гуманізм, активність чи лояльність. За цих умов політика перетворюється у різновид підприємництва, де провокуються події, конфлікти, створюються штучні іміджи лідерів, набуває самодостатнього характеру політична реклама» [Горбатенко 2006: 68]. Саме 3 перемогою Володимира Зеленського на виборах президента, Україна перейшла в інформаційне суспільство, де вся політика відбувається на екрані, і де постійним елементом є симулякр.

За визначенням енциклопедії сучасної України, інформаційне суспільство соціологічна концепція постіндустріального суспільства; нова історична фаза розвитку суспільства, в якому виробництво, використання та споживання інформації 
стає визначальним способом діяльності в усіх сферах суспільного буття (економіці, політиці та культурі).

Філософ постмодерну Ж. Бодріяр розглядає симулякри як соціальні уявлення, як безвихідь, в який зайшло людство, висуває тезу про втрату реальності в постмодерністську еру, на зміну якої приходить гіперреальність [Бодріяр 28]. Це означає, що ми живемо в світі симуляції, в світі, де вищим завданням знаку є примусити реальність зникнути i, одночасно, замаскувати це зникнення. Всі знаки нині обмінюються один на іншого, але не означають нічого реального. Ж. Бодріяр пише: «У нас тепер насправді царство повної свободи - всезагальної ні-до-чого- не-прив 'язаності, нікому-не-зобов' язанності, ні-в-що-невіри. Детермінованість померла - тепер нашою царицею $є$ не детермінованість» [Бодріяр: 43].

Також суттєвою ознакою постмодерну є, за твердженням дослідника Д. Шевчука, зникнення традиційних авторитетів. На зміну інтелектуалам та політикам приходять спортсмени, артисти, шоумени [Шевчук: 51]. Саме так і сталося у випадку із Україною. Натомість твердження, яке наразі є досить поширеним, що «актор став Президентом» є невірним, оскільки Президентом став політик Володимир Зеленський, який ще 2014 року почав їздити у зону АТО разом зі студією «Квартал95» (і того ж року вони почали надавати матеріальну допомогу військовослужбовцям).

Тому є зрозумілим, що людина, яка сьогодні отримує цей статус бажає і в політиці використовувати правила своєї минулої діяльності (амплуа «жартівника» у Володимира Зеленського). У зв'язку з цим часто приймаються імпульсивні ходи.

Науковець А. Постол також підкреслює, що багатозначність, іронія, несподіваність інтерпретацій, зворотність смислу й оцінок, гра смислами, невизначеність, фрагментарність свідомості і культури, деканонізація, видимість, ілюзія існування замість реалістичності, колажність, перевага інтуїції над раціональністю, образність, метафоричність, невиразність - це далеко не повний перелік рис постмодерну, що проявляються в усіх сферах буття соціуму [Постол 2010: 6].

Також окрему увагу на становлення В. Зеленського як політика слід приділити проєкту «Чистоnews» виробництва Кварталу 95 на телеканалі «1+1», де Зеленський був одним із ведучих. Жанр цієї передачі - політична публіцистика. Науковець-журналістикознавець В. Здоровега визначає головну специфічну функцію 
публіцистики - формування громадської думки [Здоровега 2004: 218]. У свою чергу журналістикознавець Йосип Лось зазначає «Публіцистика - це словесна сфера моделювання свідомості, вияв незгасної активності, політичне й моральнофілософське освоєння історії та актуальної суспільної практики, всеохопний засіб формування особистості, площина вияву інтересів та вартостей людей, соціальних груп і націй, втілення їх культурної ідентичності». Відповідно, участь В. Зеленського у цьому проекті також мала деяку роль у його перемозі на виборах.

Постмодерністський вимір сучасної цивілізації характеризується ускладненою ідентичністю індивідів, фрагментацією цілого і також занепадом традиційних соціальних інститутів. Тому всі ці риси нового світосприйняття людини мали вплив на виборчу кампанію кандидата у Президенти Володимира Зеленського. Відтак перемога Зеленського у президентських виборах зумовлена зміною сприйняття сучасного українського політичного дискурсу в бік постмодерністського як авторами та виконавцями передвиборчої політики Зеленського, так і виборцями, які і складають сучасний політичний простір в Україні.

\section{ЛІТЕРАТУРА}

Бодріяр „Ж. Симулякри і симуляції URL: https://reader.bookmate.com/leb6iyez.

Хайдеггер, M. Язык бытия URL: http://www.ereading.life/chapter.php/127706/453/Gricanov_-_Postmodemizmhtml.

Горбатенко, В. П. Політичне прогнозування: Теорія, методологія, практика, «Генеза», 2006. URL: http://maup.com.ua/assets/files/lib/book/nw38.pdf.

Здоровега, В. Й. Теорія і методика журналістської творчості, «ПАIC», 2004. URL: http://194.44.152.155/elib/local/sk682275.pdf.

Постол, А. А. Постмодернізм як суспільно-політична реальність, «Гуманітарний вісник ЗДІА», 2010. URL: http://www.zgia.zp.ua/gazeta/VISNIK_42_8.pdf.

Шевчук, Д. М. Постмодерні виміри політичної філософії, «Збірник наукових праць Рівненського державного гуманітарного університету», URL: https://eprints.oa. edu.ua/3748/1/Shevchuk.pdf. 